\title{
ASSESSMENT OF NOISE POLLUTION FROM SAWMILL ACTIVITIES IN ILORIN, NIGERIA
}

\author{
A. S. Aremu1 1 A. O. Aremu² and D. O. Olukanni ${ }^{3}$ \\ 1 DEPARTMENT OF WATER RESOURCES \& ENVIRONMENTAL ENGINEERING, UNIVERSITY OF ILORIN, ILORIN, NIGERIA \\ 2 DEPARTMENT OF CIVIL ENGINEERING, UNIVERSITY OF ILORIN, ILORIN, NIGERIA \\ 3 DePARTMENT OF Civil EngineERING, CovenANT University, OTA, OGUn STATE, NigERIA \\ Email Addresses:12aremu_adeniyi@yahoo.com;2aremufunmi@gmail.com;3 david.olukanni@covenantuniversity.edu.ng
}

\begin{abstract}
This study examined noise pollution from sawmilling in Ilorin metropolis, Nigeria. Noise measurements were made using HD600 digital data logging sound level meter in conjunction with structured questionnaire which was designed to elicit noise related information. The results of the study showed that the background noise within the sawmills was 58.1-64.86 $d B(A)$ while machine equivalent noise was 81.1-112.3 dB(A). Approximately 73\% of all the noise measurements are above the recommended limit of $85 \mathrm{~dB}(A)$ and these high noise intensities can initiate or perpetuate some work related health challenges. Also a noise contour map which shows the spatial impact of sawmill noise on the metropolis was developed. Within the sawmills, most of the workers are unprotected, disturbed and complain of noise-related ailments such as tinnitus (96.6\%), headache (86.6\%) and hearing impairment (71.9\%). Therefore noise prevention and control strategies are suggested in addition to frequent audiometric tests, training, education, and enforcement of noise regulations.
\end{abstract}

Keywords: Noise, sawmill, machine, workers, impacts

\section{INTRODUCTION}

Exposure to high levels of noise, particularly at workplaces, has been a global concern as strong evidence links them with some high-ranking health challenges. Symptoms of short or long periods of exposure to noise include auditory effects such as auditory fatigue and hearing loss, and indirect nonauditory effects such as speech interference, annoyance, lowered mental peace and task performance, and several psychological changes [1-7]. It was reported by the World Health Organization [8] that throughout the world, noise-induced hearing impairment is the most prevalent irreversible occupational hazard and an estimated 120 million people have disabling hearing difficulties. In addition, $16 \%$ of total global deafness is estimated to be caused by occupational noise and more than 4 million Disability-Adjusted Life Years (DALYs) are lost to noise induced hearing loss [9].

General awareness of the effects of occupational noise has led to promulgation of several legislations which prescribe permissible noise level at workplaces. Levels below $80 \mathrm{~dB}(\mathrm{~A})$ has been agreed by most experts to result in minimal risk of hearing loss development [9]. A study by the International Institute of Noise Control Engineering [10] indicated that the 8-hour average A-weighted sound pressure level legislations in twenty-four countries vary from
85 to $90 \mathrm{~dB}(\mathrm{~A})$ except China which recommends 70 $90 \mathrm{~dB}(\mathrm{~A})$. However, $85 \mathrm{~dB}(\mathrm{~A})$ continuous sound pressure level for 8 hours is the widely recommended exposure limit as contained in OSH [3], I-INCE [10], NOHSC [11], (NIOSH [12], ACGIH[13], and NESREA [14]. Regulatory standards are justified by the adverse effect of noise on public health as shown by scientific and technical data as well as consideration of technological feasibility, costs of compliance, prevailing exposure levels, and social-economic and cultural conditions [8].

Noise in several industrial workplaces has been extensively studied in literature. Some of these studies investigated noise pollution in a single workplace i.e. refinery [15], textile factory [16], quarry [17], integrated steel plant [18], mining industry [19], oil mill [20], construction site [21], oil and gas installation [22] and cement factory [23]. Other studies focused on multiple workplaces i.e. steel pipe and air conditioning unit factory [24], sawmills, printing presses and corn mills [25], concrete traverse, cement, iron and steel, and textile factories [26], and fifteen industrial sites [27]. The noise level reported by these studies with diverse machinery and operating environment varies considerably. Generally, workplaces in the industrial sector have not only generated huge amounts of noise; they have equally witnessed enormous increase in number and diversification. 
Wood has been useful to human societies since ancient civilizations and wood resources continue to play dominant roles in the world as the demand for wood products is on the increase [28]. The building construction industry has also witnessed tremendous growth and wood from logs serves as a major construction material. However, lumber mills, where logs are processed have been identified as an extreme acoustic environment for workers [29]. In particular, sawmill activities in lumber mills could generate appreciable amount of noise as a result of machine engine operation, cutting and sawing, and these activities occur every day for long periods of time.

Nigeria is Africa's largest wood producer with an annual harvest of more than 100 million cubic meters [30]. Sawmills are majorly domiciled in cities and they account for $93.32 \%$ of the total wood-based industries [31]. However, there is paucity of information on noise from sawmill activities within the cities in Nigeria. The purpose of this study is to establish and characterize noise from sawmilling in Ilorin city, Nigeria, determine its impact on sawmill workers and urban environment, and proffer mitigation strategies.

\section{METHODOLOGY}

\subsection{Study area}

The city of Ilorin is the largest urban centre and capital of Kwara State in North Central Nigeria. Ilorin lies on latitude $8^{\circ} 30^{\prime} \mathrm{N}$ and longitude $4^{\circ} 35^{\prime} \mathrm{E}$, occupies an area of $89 \mathrm{~km}^{2}$ and has a population of about 800,000 [32]. Ilorin has a tropical wet and dry climate, relative humidity of $79.7 \%$, and its vegetation falls within the derived Savannah [33]. The proximity of Ilorin to some rainforest states and its unique geographical location as the "gateway" between the northern and southern parts of the country makes it possible to regularly receive logs for sawmilling and lumbers/planks for further processing prior to marketing for local consumption or transportation to the northern parts of Nigeria [34]. However, the thriving sawmill activities is one of the businesses which produce negative environmental impacts including noise pollution. For the purpose of this study, noise from the major sawmills within Ilorin metropolis totalling sixteen was investigated. The identity and location of the studied sawmills is presented in Table 1 and their spatial distribution within the metropolis is shown in Figure 1.

\subsection{Sawmill noise measurements}

Noise measurements were taken from the sixteen prominent sawmills using a sound level meter because it closely replicates the loudness perceived by the human ear [35]. The sound level meter used in this study is the digital datalogging sound level meter, model HD600 manufactured by Extech ${ }^{\circledR}$ Instruments Corporation, U.S.A. The equipment meets Type 2 requirements of ANSI S1.4 and IEC 61672-1, and measures and displays Sound Pressure Level (SPL) from $30 \mathrm{~dB}(\mathrm{~A})$ to $130 \mathrm{~dB}(\mathrm{~A})$ with $\pm 1.4 \mathrm{~dB}(\mathrm{~A})$ accuracy in 3 measurement ranges. For each sawmill, the background noise was taken when the sawmill is active but the machines are not in operation. Noise measurements were then taken at each machine location when in operation with one set of readings taken in triplicates in each of the four cardinal points to increase accuracy of the readings.

Table 1: Sawmill identity and location

\begin{tabular}{clcc}
\hline $\begin{array}{c}\text { Sawmi } \\
\text { ll }\end{array}$ & \multicolumn{1}{c}{ Location } & $\begin{array}{c}\text { Longitu } \\
\text { de }\end{array}$ & $\begin{array}{c}\text { Latitud } \\
\mathrm{e}\end{array}$ \\
\hline SM1 & Bankole Plank Market, off Tanke & 4.61000 & 8.4796 \\
SM2 & Road & 4.58030 & 8.4559 \\
Ganmo & Off F Division, Pipeline Road, & 4.61900 & 8.4934 \\
SM4 & Tanke & 4.55020 & 8.4573 \\
SM5 & Saboline Area & 4.55830 & 8.4951 \\
SM6 & Idiose, Alore & 4.52920 & 8.5059 \\
SM7 & Odo-Okun, off Sawmill Garage & 4.52620 & 8.4707 \\
SM8 & Road & 4.59680 & 8.4257 \\
SM9 & Agbabiaka & 4.60280 & 8.4642 \\
SM10 & Adangba Area & 4.53860 & 8.5054 \\
SM11 & Olorunshogo, off Yebumot Road & 4.51740 & 8.4629 \\
SM12 & Abiola Off Cocacola Road & 4.55700 & 8.4662 \\
SM13 & Amayo & 4.62790 & 8.4141 \\
SM14 & Alagbado, off Sobi Road & 4.53930 & 8.5228 \\
SM15 & Ifesowapo, off Jebba Road, Sango & 4.58790 & 8.5111 \\
SM16 & Oyun & 4.60620 & 8.5296 \\
\hline & & &
\end{tabular}

The third set of readings were taken at predetermined sampling points within each sawmill when all the machines are in operation. The prescribed procedure stipulated in HD600 User's Guide and the WHO document containing strategies for conducting noise surveys [36] was followed in taking all the measurements. The sound level meter was positioned at a height of $1.5 \mathrm{~m}$ above the ground and at least $1.5 \mathrm{~m}$ away from reflecting surfaces. The sound level meter was set to slow response measurement of A-weighted sound levels at a sampling interval of $1 \mathrm{~s}$.

The noise descriptors used in the study are:

a) Maximum noise level ( $\left.L_{\max }\right)$ : Peak measured sound pressure during the measurement period

b) Average noise level ( $\left.L_{p}\right)$ is given as:

$$
L_{p}=20 \log \frac{1}{n} \sum_{j=1}^{n} 10^{\left(\frac{L_{j}}{20}\right)}
$$

In (1), $n$ is the number of SPL readings taken; $L_{j}=f^{\text {th }}$ SPL; for $j=1,2,3, \ldots, n$

c) Equivalent SPL ( $L_{e q}$ ): constant noise level that, over a given time, expends the same amount of energy as the varying sound level over the same period of time. Mathematically, it is represented as:

$L_{e q}=10 \log \sum_{i=t}^{i=n}\left(10^{\frac{L_{i}}{10}}\right)\left(t_{i}\right)$ 


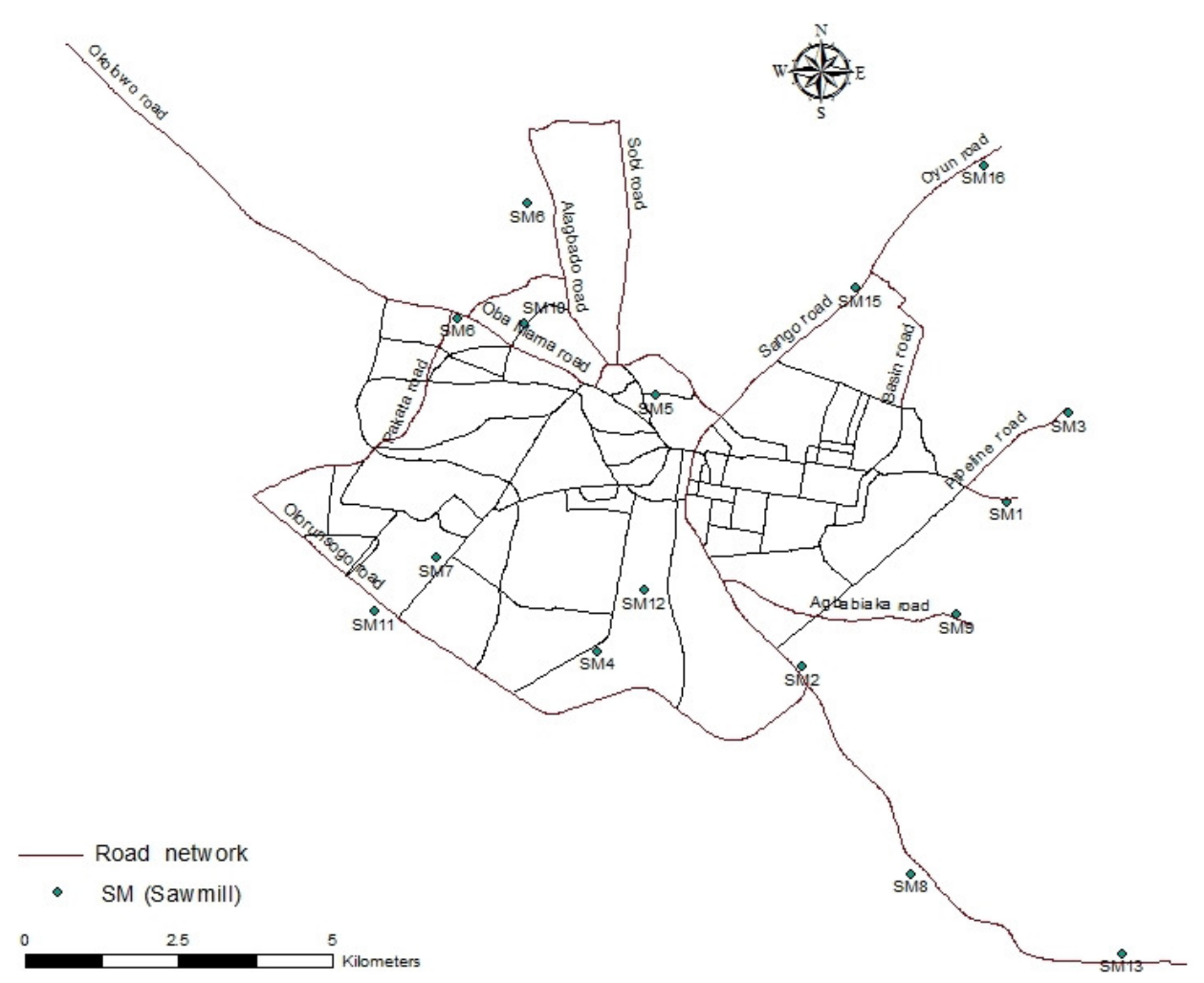

Figure 1: Spatial location of the studied sawmills within Ilorin metropolis

In (2), $\mathrm{n}$ is the total number of SPL samples taken, $\mathrm{L}_{i}$ is the SPL in the $t^{\text {th }}$ sample and $t_{i}$ is the fraction of total SPL sample time.

\subsection{Questionnaire survey}

In order to validate physically measured sound exposure, social surveys such as administration of questionnaire to obtain subjective response of human beings is appropriate [4]. A structured questionnaire was designed to capture data on noise rating, health status, existing information on sawmill equipment and working conditions in the sawmill. A total of 350 questionnaires were administered to randomly selected workers, particularly the machine operators. In some instances illiterate subjects were assisted in completing the questionnaire. The solicited data included background information of the subject, source(s) of work area noise, working equipment noise information, subjective noise rating, observed effects of noise, and use of noise protector.

\section{RESULTS AND DISCUSSION}

\subsection{Noise exposure measurements}

Background noise represents the ambient environmental noise level when no machine is in operation. The background noise in the studied sawmills is presented in Figure 2. The average background noise ranges from $58.1 \mathrm{~dB}(\mathrm{~A})$ in SM11 to $64.86 \mathrm{~dB}(\mathrm{~A})$ in $\mathrm{SM} 15$. This value is expected because most of the sawmills are surrounded by other flourishing industrial and commercial activities which are equally situated close to major roads that are known to generate appreciable traffic noise. Also the measured background noises fall within L90 values of 34-74 $\mathrm{dB}(\mathrm{A})$ reported by Oyedepo [37] for some sampling points within Ilorin metropolis. However, these values are still within permissible noise levels of $75 \mathrm{~dB}(\mathrm{~A})$ stipulated by the World Health Organization (WHO) [8] for industrial, commercial, and traffic areas.

The noise generating machines found in the studied sawmills are circular, planning, ripsaw, and rabetting machine while band-saw and chainsaw was found only at Irewolede sawmill (SM4). The equivalent noise generated by the machines is presented in Table 2 .

Typical noise in all other machines range between 81.1 and $98.8 \mathrm{~dB}(\mathrm{~A})$. Band saw and chain saw were observed to generate the highest noise of 106.4 and $112.3 \mathrm{~dB}(\mathrm{~A})$ respectively. A total of $84 \%, 84 \%, 71 \%$, $49 \%, 99 \%$, and $100 \%$ of all the readings taken at the circular, planning, ripsaw, rabbeting, band-saw, and chainsaw machine respectively exceeded the permissible level of $85 \mathrm{~dB}(\mathrm{~A})$ specified by the National Environmental Standards and Regulations Enforcement Agency (NESREA).

The distribution of noise within the metropolis when the sawmills are in operation in the form of a noise contour map is presented in Figure 3. The contour displays the footprints of individual sawmill activity, joins points having the same noise level, and also reflects the cumulative noise exposure due to all sawmill activities within data boundary. 


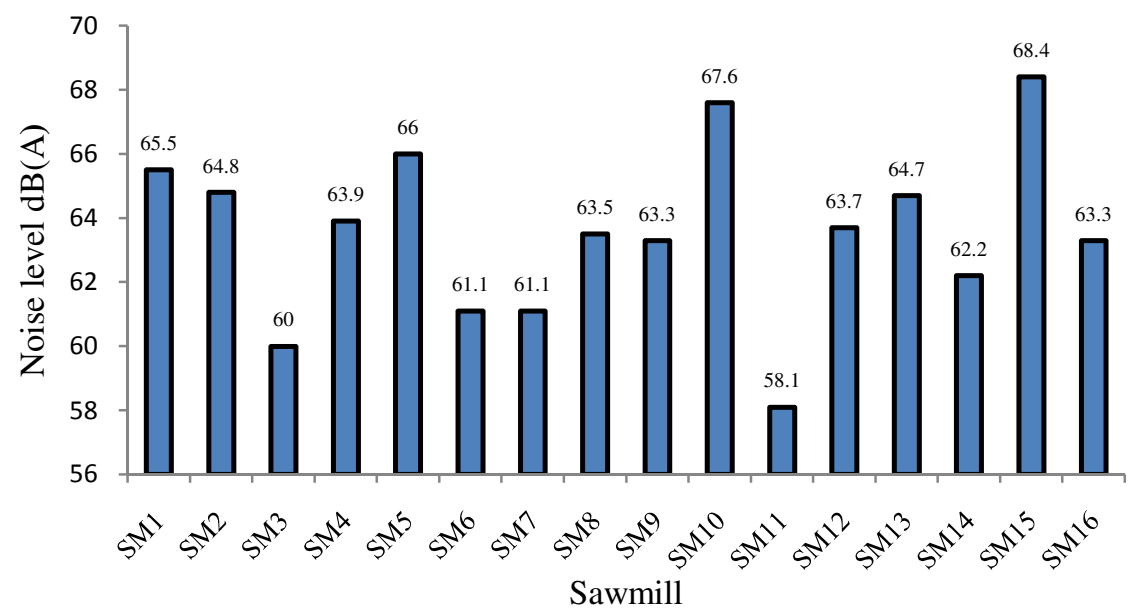

Figure 2: Average background noise in the studied sawmills

Table 2: Equivalent noise level of machines in the sawmills

\begin{tabular}{|c|c|c|c|c|c|c|c|c|c|c|c|c|}
\hline \multirow{2}{*}{$\begin{array}{c}\text { Type of machine } \\
\begin{array}{l}\text { Sawmill } \\
\text { identity }\end{array}\end{array}$} & \multicolumn{2}{|c|}{ Circular Saw } & \multicolumn{2}{|c|}{ Planning } & \multicolumn{2}{|c|}{ Rabbeting } & \multicolumn{2}{|c|}{ Ripsaw } & \multicolumn{2}{|c|}{ Band Saw } & \multicolumn{2}{|c|}{ Chain Saw } \\
\hline & $\%>\mathrm{PL}$ & $\begin{array}{c}\mathrm{Leq}_{\mathrm{eq}} \\
\mathrm{dB}(\mathrm{A})\end{array}$ & $\%>\mathrm{PL}$ & $\begin{array}{c}\mathrm{Leq}_{\mathrm{eq}} \\
\mathrm{dB}(\mathrm{A})\end{array}$ & $\%>\mathrm{PL}$ & $\begin{array}{c}\mathrm{Leq}_{\mathrm{eq}} \\
\mathrm{dB}(\mathrm{A})\end{array}$ & $\%>\mathrm{PL}$ & $\begin{array}{c}\mathrm{Leq}_{\mathrm{eq}} \\
\mathrm{dB}(\mathrm{A})\end{array}$ & $\%>\mathrm{PL}$ & $\begin{array}{c}\mathrm{Leq}_{\mathrm{eq}} \\
\mathrm{dB}(\mathrm{A})\end{array}$ & $\%>\mathrm{PL}$ & $\begin{array}{c}\mathrm{L}_{\mathrm{eq}} \\
\mathrm{dB}(\mathrm{A})\end{array}$ \\
\hline SM1 & 87 & 94.2 & 89 & 97.8 & 64 & 93.8 & 87 & 93.7 & $\mathrm{~N} / \mathrm{A}$ & $\mathrm{N} / \mathrm{A}$ & $\mathrm{N} / \mathrm{A}$ & $\mathrm{N} / \mathrm{A}$ \\
\hline SM2 & 86 & 95.5 & 91 & 97.4 & 70 & 94.8 & 87 & 94.4 & $\mathrm{~N} / \mathrm{A}$ & $\mathrm{N} / \mathrm{A}$ & $\mathrm{N} / \mathrm{A}$ & $\mathrm{N} / \mathrm{A}$ \\
\hline SM3 & 80 & 94.7 & 81 & 95.3 & 87 & 92.9 & 13 & 83.1 & $\mathrm{~N} / \mathrm{A}$ & $\mathrm{N} / \mathrm{A}$ & $\mathrm{N} / \mathrm{A}$ & $\mathrm{N} / \mathrm{A}$ \\
\hline SM4 & 79 & 94.2 & 78 & 96.3 & 84 & 95.1 & 58 & 86.2 & 99 & 106.4 & 100 & 112.3 \\
\hline SM5 & 86 & 95.5 & 88 & 96.8 & 74 & 92.3 & 84 & 88.0 & $\mathrm{~N} / \mathrm{A}$ & $\mathrm{N} / \mathrm{A}$ & $\mathrm{N} / \mathrm{A}$ & $\mathrm{N} / \mathrm{A}$ \\
\hline SM6 & 89 & 94.4 & 90 & 95.8 & 79 & 94.2 & 46 & 89.3 & $\mathrm{~N} / \mathrm{A}$ & $\mathrm{N} / \mathrm{A}$ & $\mathrm{N} / \mathrm{A}$ & $\mathrm{N} / \mathrm{A}$ \\
\hline SM7 & 85 & 96.7 & 85 & 96.0 & 82 & 94.6 & 27 & 84.1 & $\mathrm{~N} / \mathrm{A}$ & $\mathrm{N} / \mathrm{A}$ & $\mathrm{N} / \mathrm{A}$ & $\mathrm{N} / \mathrm{A}$ \\
\hline SM8 & 94 & 95.8 & 96 & 95.8 & 94 & 94.2 & 34 & 87.8 & $\mathrm{~N} / \mathrm{A}$ & $\mathrm{N} / \mathrm{A}$ & $\mathrm{N} / \mathrm{A}$ & $\mathrm{N} / \mathrm{A}$ \\
\hline SM9 & 72 & 97.2 & 80 & 96.7 & 45 & 92.3 & 32 & 91.2 & $\mathrm{~N} / \mathrm{A}$ & $\mathrm{N} / \mathrm{A}$ & $\mathrm{N} / \mathrm{A}$ & $\mathrm{N} / \mathrm{A}$ \\
\hline SM10 & 73 & 95.3 & 83 & 97.2 & 62 & 91.0 & 8 & 81.1 & $\mathrm{~N} / \mathrm{A}$ & $\mathrm{N} / \mathrm{A}$ & $\mathrm{N} / \mathrm{A}$ & $\mathrm{N} / \mathrm{A}$ \\
\hline SM11 & 91 & 95.4 & 98 & 97.7 & 83 & 88.8 & 18 & 83.9 & $\mathrm{~N} / \mathrm{A}$ & $\mathrm{N} / \mathrm{A}$ & $\mathrm{N} / \mathrm{A}$ & $\mathrm{N} / \mathrm{A}$ \\
\hline SM12 & 84 & 98.2 & 70 & 95.6 & 52 & 91.2 & 41 & 87.9 & $\mathrm{~N} / \mathrm{A}$ & $\mathrm{N} / \mathrm{A}$ & $\mathrm{N} / \mathrm{A}$ & $\mathrm{N} / \mathrm{A}$ \\
\hline SM13 & 83 & 96.1 & 80 & 94.2 & 72 & 90.9 & 84 & 92.0 & $\mathrm{~N} / \mathrm{A}$ & $\mathrm{N} / \mathrm{A}$ & $\mathrm{N} / \mathrm{A}$ & $\mathrm{N} / \mathrm{A}$ \\
\hline SM14 & 88 & 97.0 & 76 & 96.5 & 56 & 90.6 & 48 & 89.4 & $\mathrm{~N} / \mathrm{A}$ & $\mathrm{N} / \mathrm{A}$ & $\mathrm{N} / \mathrm{A}$ & $\mathrm{N} / \mathrm{A}$ \\
\hline SM15 & 81 & 98.2 & 85 & 95.9 & 53 & 90.6 & 48 & 89.6 & N/A & $\mathrm{N} / \mathrm{A}$ & $\mathrm{N} / \mathrm{A}$ & $\mathrm{N} / \mathrm{A}$ \\
\hline SM16 & 82 & 98.8 & 77 & 96.7 & 76 & 93.3 & 62 & 90.4 & $\mathrm{~N} / \mathrm{A}$ & $\mathrm{N} / \mathrm{A}$ & $\mathrm{N} / \mathrm{A}$ & $\mathrm{N} / \mathrm{A}$ \\
\hline
\end{tabular}

$\mathrm{PL}=$ Permissible Limit $(85 \mathrm{~dB}(\mathrm{~A})) \quad \mathrm{N} / \mathrm{A}=$ Not Available

The crest of the contour is at SM4 denoting the highest noise intensity $(121.7 \mathrm{~dB}(\mathrm{~A}))$ with a steep decrease towards the north to $108.8 \mathrm{~dB}(\mathrm{~A})$ at SM12. At the southern part of SM4 the contour lines are far apart with a shallow slope reaching $114 \mathrm{~dB}(\mathrm{~A})$ near the data boundary. SM4 is located within the industrial zone of the township and it houses industries like flour mill, steel industry, soap and detergent manufacturing company, pharmaceutical industry, foam industry, and several other commercial establishments. The high noise intensity in SM4 may be attributable to the operation of band-saw and chain saw machine which generate high noise and the prevailing background noise (about $63.9 \mathrm{~dB}(\mathrm{~A})$ ) from other industrial or commercial activities. Outside SM4, the noise contour is dispersed ranging between $106 \mathrm{~dB}(\mathrm{~A})$ and 115 $\mathrm{dB}(\mathrm{A})$. These noise intensities are greater than the stipulated limit of $70 \mathrm{~dB}(\mathrm{~A})$ for general environment or 85-109 $\mathrm{dB}(\mathrm{A})$ depending on duration for workshops or factories (NESREA, 2009). This constitutes a nuisance and threat to public health as it can result in several physiological and psychological disorders in workers as well as those living within the vicinity of sawmills.

\subsection{Questionnaire survey}

A total of 320 out of 350 administered questionnaires were completed, returned and useable for analysis. Table 3 shows the number of respondents with respect to their age group and gender. Majority of the 
study population (84.8\%) within sawmill workers are males while $15.2 \%$ are females. About $80 \%$ of the respondents fall within the active age group of 14-57. Most of the elderly within the age bracket of 58 and above are machine owners, union members or supervisors.

Table 3: Background information of respondents

\begin{tabular}{lll}
\hline Parameter & No. & $\%$ \\
\hline Sex: & & \\
Female & 49 & 15.2 \\
Male & 271 & 84.8 \\
\hline Age: & & \\
$14-27$ & 36 & 11.4 \\
$28-37$ & 72 & 22.5 \\
$38-47$ & 86 & 27.0 \\
$48-57$ & 61 & 19.1 \\
$58-67$ & 44 & 13.8 \\
68 and above & 21 & 6.7 \\
\hline
\end{tabular}

The result of subjective rating of noise is presented in Table 4. A total of 41 (12.9\%), 219 (68.4\%), and 56 (17.4\%) of the respondents rated sawmill noise as noisy, very noisy, and extremely noisy respectively while only $4(1.1 \%)$ claimed it is not so noisy. Therefore a total of $98.9 \%$ of respondents are dissatisfied with the level of noise in their workplace. This dissatisfaction may be attributable to the use of some high noise generating machines and some experimental effects of noise.

The claims by the studied population on the effects on noise are varied and many respondents made multiple complaints. As presented in Table 5, out of the complaints extracted from the questionnaires, majority was tinnitus (96.6\%), headache (86.6\%) and hearing loss (71.9\%). Fewer complaints were observed of annoyance (3.3\%), difficulty in concentration (2.5\%), and diplacusis (1.8\%). According to WHO [9], tinnitus can cause sleep disturbance, cognitive impairment, anxiety, psychological distress, depression, communication hindrance, frustration, irritability, tension, loss of work productivity, reduced efficiency and restricted participation in social life

Table 4: Respondents' rating of sawmill environment

\begin{tabular}{lll}
\hline Rating & No & $\%$ \\
\hline Extremely quiet & 1 & 0.2 \\
Quiet & 3 & 0.9 \\
Noisy & 41 & 12.9 \\
Very Noisy & 219 & 68.4 \\
Extremely Noisy & 56 & 17.4 \\
\hline
\end{tabular}

Headaches are one of the most common neurological problems which are painful and debilitating, and cause a substantial health and social burden on the society [38]. Pain resulting from headaches may be accompanied by nausea or increased sensitivity to noise or light and may signal a more serious disorder that requires prompt medical attention [39]. Generally, it is observed that continued exposure to noise above $80 \mathrm{~dB}(\mathrm{~A})$ will result in some hearing loss over time [2] and an appreciable amount of healthy life is lost to noise induced hearing loss. Also, the annoying effect of noise is a function of noise levels and exposure time whilst high noise levels for short periods are more annoying than lower levels at relatively longer periods [40]. It is therefore necessary to control noise within sawmills.

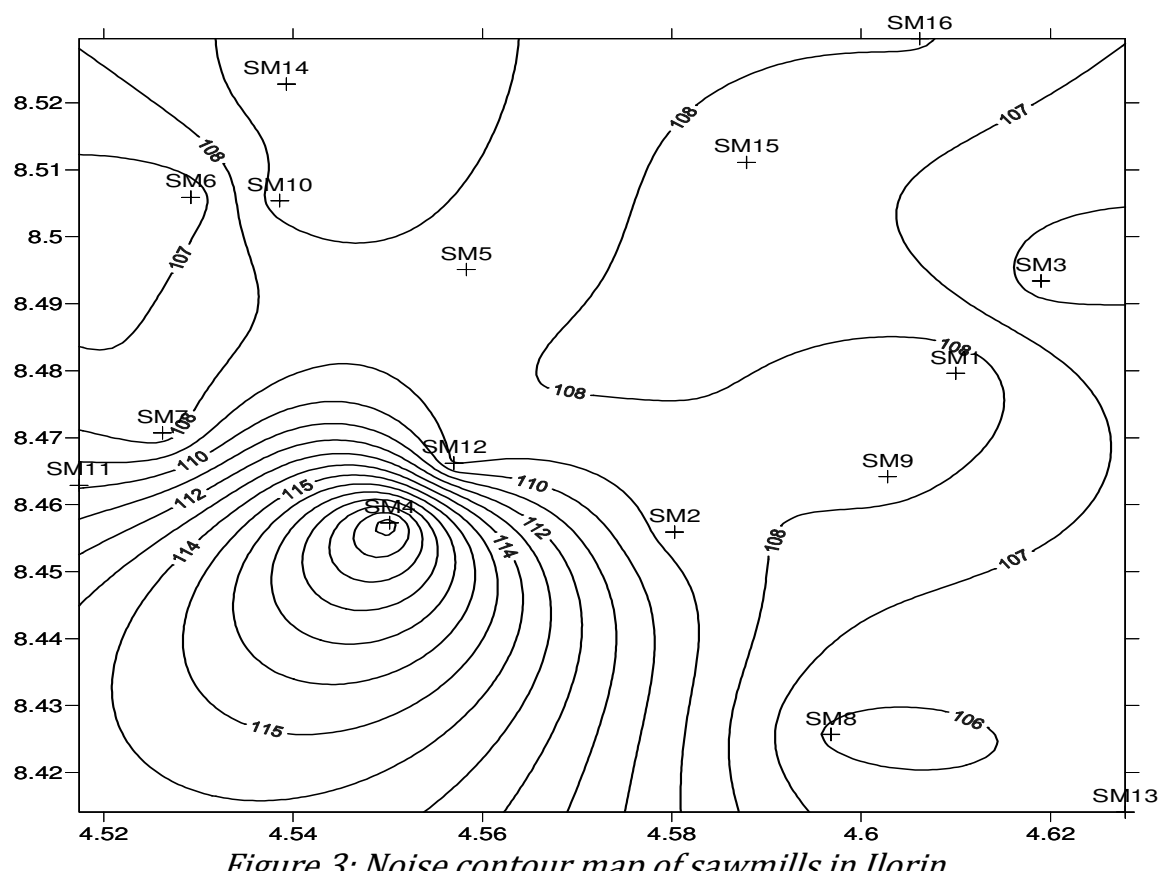

Figure 3: Noise contour map of sawmills in Ilorin 
Table 5: Percentage of workers having noise related complaints

\begin{tabular}{ll}
\hline Complaint & No. of complaints (\%) \\
\hline Headache & $277(86.6)$ \\
Hearing loss & $230(71.9)$ \\
Annoyance/irritability & $29(9.1)$ \\
Difficulty in concentration & $22(6.9)$ \\
Tinnitus & $309(96.6)$ \\
Diplacusis & $16(5.0)$ \\
\hline
\end{tabular}

Table 6 shows information on how noise is controlled at sawmills within Ilorin. Hearing protectors are not available to approximately $97 \%$ of sawmill workers and usage of protectors is extremely low (1.3\%). Also machinery noise propagation control such as use of barriers, sound proofing are not available. Hence over $98 \%$ of workers are not under any protection and are exposed to high sawmill noise. This study equally noticed that only 8 out of the 320 respondents have undergone hearing tests, hence it is confirmed that most workers do not know their hearing status and may not be able to monitor the likely effects of their exposure to sawmill noise. Perhaps noise tests are not carried out because of lack of training, education, and enforcement of noise regulations.

Table 6: Noise preventive methods taken by respondents

\begin{tabular}{lll}
\hline & Yes (\%) & No (\%) \\
\hline $\begin{array}{l}\text { Availability of hearing } \\
\text { protector }\end{array}$ & $11(3.4)$ & $309(96.6)$ \\
$\begin{array}{l}\text { Usage of hearing protector } \\
\text { Machinery noise }\end{array}$ & $4(1.3)$ & $316(98.7)$ \\
propagation control & $6(1.9)$ & $314(98.1)$ \\
Hearing status test & $8(2.5)$ & $3127.5)$ \\
\hline
\end{tabular}

\section{CONCLUSIONS}

The study has shown that sawmills have problem of noise emanating from machining operations despite permissible levels of background noise. The measured background noise varied from 58.1-64.86 $\mathrm{dB}(\mathrm{A})$ while machine equivalent noise ranged between 81.1 $\mathrm{dB}(\mathrm{A})$ and $112.3 \mathrm{~dB}(\mathrm{~A})$. The maximum noise level in the studied sawmills from several combinations of machine operations was 105.6 to $121.7 \mathrm{~dB}(\mathrm{~A})$. The crest of the developed noise contour map was at SM4, thus denoting the sawmill with highest sum of background and machine operation noise relative to other sawmills within the metropolis. More so approximately $73 \%$ of all the measurements were above the recommended limit of $85 \mathrm{~dB}(\mathrm{~A})$.

Furthermore, a total of $98.9 \%$ of sawmill workers are dissatisfied with the level of noise in the sawmills. It was also observed that almost all workers are not under any form protection and are exposed to high sawmill noise. Also machinery noise propagation controls are unavailable and workers operating or working in the vicinity of the chain saw are the most affected. The most prominent health complaints by sawmill workers is tinnitus (96.6\%), headache $(86.6 \%)$ and hearing loss (71.9\%). Consequently evidence from obtained noise levels and subjective response from sawmill workers suggests the implementation of noise prevention and control strategies in addition to training, education, and enforcement of noise regulations.

\section{ACKNOWLEDGMENT}

The authors gratefully acknowledge the support received from the staff and union leaders of each sawmill.

\section{REFERENCES}

1. Bryan, M. and Tempest, W. "Cause for concern-noise pollution of the work environment", International Journal of Environmental Studies, Vol. 1, Number 14, 1970, pp. 99-105.

2. Edworthy, J. "Noise and its effects on people: an overview", International Journal of Environmental Studies, Vol. 51, Number 4, 1997, pp. 335-344.

3. OSH. Approved Code of Practice for the Management of Noise in the Workplace: OSH 3280, Department of Labour, Occupational Safety and Health Service, Wellington, 2002.

4. Ambekar, A.G. Mechanical Vibrations and Noise Engineering. PHI Learning Private Limited, New Delhi, 2006.

5. Duggal, K.N. Elements of Environmental Engineering. S.Chand \& Company Ltd, New Delhi, 2007.

6. Juang, D.F., Lee, C.H., Yang, T. and Chang, M.C. "Noise pollution and its effects on medical care workers and patients in hospitals", International Journal of Environmental Science and Technology, Vol. 7, Number 4, 2010, pp. 705-716.

7. Oyedepo, O.J. "Evaluating performances of traffic noise models", Nigerian Journal of Technology, Vol. 33, Number 4, 2014, pp. 442-446.

8. WHO. Guidelines for Community Noise, World Health Organization, Switzerland, 1999.

9. WHO. Occupational Noise: Assessing the Burden of Disease from Work-Related Hearing Impairment at National and Local Levels. Environmental Burden of Disease Series, No. 9, World Health Organization, Switzerland, 2004.

10. Embleton, T.F.W. Technical Assessment of Upper Limits on Noise in the Workplace. Final Report: IINCE Publication 97-1.: The International Institute of Noise Control Engineering and the Institute of Noise Control Engineering; 1997. 
11. NOHSC. Noise Management at Work: Control Guide [NOHSC: 12004(1991), (2nd ed.), National Occupational Health and Safety Commission, Worksafe, Sydney, Australia, 1991.

12. NIOSH. Criteria for a Recommended StandardOccupational Exposure to Noise - Revised Criteria 1998, Publication No. 98-126, National Institute of Occupational Safety and Health, U.S.A., 1998.

13. ACGIH. Documentation of the Physical Agents Threshold Limit Values, Publication 0302, American Conference of Governmental Industrial Hygienists, U.S.A., 1999.

14. NESREA. National Environmental (Noise Standards and Control) Regulations, 2009. Federal Republic of Nigeria Official Gazette, Vol. 96, No. 67, S.I. No. 35, FGP 104/102009/1,000 (OL 60), National Environmental Standards and Regulations Enforcement Agency, Federal Government Printer, Nigeria, 2009.

15. Wachasunder, S. "Assessment of refinery noise impact on workers - a case study", International Journal of Environmental Studies, Vol. 61, Number 4, 2004, pp. 459-470.

16. Bedi, R. "Evaluation of occupational environment in two textile plants in northern India with specific reference to noise", Industrial Health, Vol. 44, 2006, pp. 112-116.

17. Adie, D.B., Otun, J.A., Okuofu, C.A. and Nasiru, A. "Assessment of noise generated by operations within the Gunduwawa quarry in Kano State, Nigeria", Nigerian Journal of Technology, Vol. 31, Number 3, 2012, pp. 314-320.

18. Kerketta, S., Dash, P.K. and Narayan, L.T.P. "Work zone noise levels at Aarti steel plant, Orissa and its attenuation in far field", Journal of Environmental Biology, Vol. 30, Number 5, 2009, pp. 903-908.

19. Sensogut, C. "Occupational noise in mines and its control - a case study", Polish Journal of Environmental Studies, Vol. 16, Number 6, 2007, pp. 939-942.

20. Kumar, G.V.P., Dewangan, K.N. and Sarkar, A. "Noise exposure in oil mills", India Journal of Occupational and Environmental Medicine, Vol. 12, Number 1, 2008, pp. 23-28.

21. Hamoda, M.F. "Modeling of construction noise for environmental impact assessment", Journal of Construction in Developing Countries, Vol. 13, Number 1, 2008, pp. 79-89.

22. Alao, A.A. and Avwiri, G.O. "Noise levels associated with selected oil and gas installations in Ogba/Egbema/Ndoni Local Government Area of Rivers State, Nigeria", Journal of Environmental Issues and Agriculture in Developing Countries, Vol. 2, Number 2 \& 3, 2010, pp. 42-47.

23. Mndeme, F.G. and Mkoma, S.L. "Assessment of work zone noise levels at a cement factory in Tanga,
Tanzania", Ethiopian Journal of Environmental Studies and Management, Vol. 5, Number 3, 2012, pp. 225-231.

24. Ahmed, H.O., Dennis, J.H., Badran, O., Ismail, M., Ballal, S.G., Ashoor, A. and Jerwood, D. "Occupational noise exposure and hearing loss of workers in two plants in Eastern Saudi Arabia", Annals of Occupational Hygiene, Vol. 45, Number 5, 2001, pp. 371-380

25. Boateng, C.A. and Amedofu, G.K. "Industrial noise pollution and its effect on hearing capabilities of workers: A study from sawmills, printing presses and corn mills", African Journal of Health Science, Vol. 11, Number 1-2, 2004, pp. 55-60.

26. Atmaca, E., Peker, I. and Altin, A. "Industrial noise and its effects on humans", Polish Journal of Environmental Studies, Vol. 14, Number 6, 2005, pp. 721-726.

27. Ali, S.A. "Industrial noise levels and annoyance in Egypt", Applied Acoustics, Vol. 72, Number 4, 2011, pp. 221-225.

28. Forest Products Laboratory. Wood Handbook-Wood as an Engineering Material. General Technical Report FPL-GTR-190, United States Department of Agriculture, U.S.A., 2010.

29. Davies, H.W., Teschke, K., Kennedy, S.M., Hodgson M.R. and Demers P.A. "Occupational noise exposure and hearing protector use in Canadian lumber mills", Journal of Occupational and Environmental Hygiene, Vol. 6, Number 1, 2008, pp. 32-41.

30. Aruofor, R.0. The Nigerian Forestry Outlook Study. 2001 <http://www.fao.org/forestry/FON/ FONS/ outlook/Africa/AFRhom-e.stm $>$ Retrieved 24 May 2014.

31. Fuwape, J.A. "Developments in wood-based industries in Nigeria", Foresea Miyazaki, Vol. 2, 1998, pp. 575-585.

32. Aremu, A.S. and Sule, B.F. "A case study evaluation of the impacts of optimized waste bin locations in a developing city", Journal of Civil Engineering and Environmental Systems, Vol. 29, Number 2, 2012, pp. 137-146.

33. Ifabiyi, I.P. "Willingness to pay for water at household level in Ilorin, Kwara State, Nigeria", Global Journal of Human Social Science, Vol. 11, Number 2, 2011, pp. 14-24.

34. Lasode, O.A., Aremu, A.S., Balogun, A.O. and Kareem, A.A. "Determination of an optimum location for a biomass waste-to-energy facility", Proceedings of the $27^{\text {th }}$ International Conference on Solid Waste Technology and Management, Philadelphia, U.S.A., 2012, pp. 853-863.

35. Kiely, G. Environmental Engineering, McGraw-Hill Co, Singapore, 1997. 
36. Gerges, S.N.Y., Sehrndt, G. and Parthey, W. Noise Sources. In: B. Goelzer, C.H. Hansen, G.A. Sehrndt (Eds) Occupational Exposure to Noise: Evaluation, Prevention and Control, Federal Institute for Occupational Safety and Health, on behalf of the World Health Organization, Germany, 2001.

37. Oyedepo, S.O. "Development of noise map for Ilorin metropolis, Nigeria", International Journal of Environmental Studies, Vol. 70, Number 4, 2013, pp. 503-514.

38. NICE. Diagnosis and Management of Headaches in Young People and Adults. Clinical Guideline 150,
National Institute for Health and Clinical Excellence, United Kingdom, 2012.

39. NINDS. Headache: Hope Through Research. NIH Publication No. 09-158 August 2009, National Institute of Neurological Disorders and Stroke, U.S.A., 2009.

40. Gjestland T. and Oftedal G. "Assessment of noise annoyance: the introduction of a threshold level in $\mathrm{L}_{\mathrm{eq}}$ calculations", Journal of Sound and Vibration, Vol. 69, Number 4, 1980, pp. 603-610. 